Check for updates

Cite this: RSC Adv., 2019, 9, 13234

Received 9th March 2019 Accepted 23rd April 2019 DOI: $10.1039 / c 9 r a 01798 d$ rsc.li/rsc-advances

\section{Explaining the influence of the introduced base sites into alkali oxide modified CsX towards side- chain alkylation of toluene with methanol $\uparrow$}

\author{
Peidong Li, ${ }^{\text {abc }}$ Qiao Han, ${ }^{\text {abc }}$ Xiaomin Zhang, ${ }^{\mathrm{b}}$ Yangyang Yuan, ${ }^{\mathrm{b}}$ Yanfei Zhang, ${ }^{\text {abc }} \mathrm{Li} \mathrm{Xu},{ }^{\mathrm{b}}$ \\ Hongchen Guo*a and Lei Xu (D)*b
}

\begin{abstract}
The effect of the introduced base sites in CsX with alkali oxide modification towards side-chain alkylation of toluene with methanol was systematically investigated in the present work. A series of alkali oxide modified CsX with a base properties (base strength and amount) gradient were prepared by impregnating CsX with alkali metal hydroxide. Here, CsX with different base strengths were selected as the parent zeolite, which is favorable to clarify the different types of base site in the modified CsX. The base properties of the samples were elucidated based on the $\mathrm{CO}_{2}$-TPD results as well as with characterization by XPS and FTIR of adsorbed $\mathrm{CO}_{2}$. It was revealed that the base strength of the oxygen atoms with negative charge $\left(\mathrm{O}^{\delta-}\right)$ in the zeolite framework can be strengthened by the electron donating function of the alkali oxides in the supercage of CsX. Detailed analysis of the correlation between the reaction behaviors of sidechain alkylation reaction and the base properties of the indicated catalysts was carried out. It was found that the dehydrogenation of methanol to formaldehyde step was promoted by the increasing base properties of $\mathrm{O}^{\delta-}$ in the CsX framework and that was the main reason for the promotion of the whole side-chain alkylation reaction. However, it was also found that the stronger base properties of the alkali oxide modified CsX would enhance the formation of active hydrogen atoms, which aggravated the unwanted styrene conversion to ethylbenzene.
\end{abstract}

\section{Introduction}

Styrene synthesis by side-chain alkylation of toluene with methanol was first reported by Sidorenko et al. in 1967. ${ }^{1}$ Since then, this reaction has attracted widespread attention and was deemed as a sustainable one-step alternative for the current two-step route through the alkylation of benzene with ethylene and sequential dehydrogenation of the ethylbenzene product. ${ }^{2,3}$ In spite of many studies in the past decades, there are still lots of unsolved problems, among which the relatively low catalytic conversion of reactants is the most urgent one as it is the main restriction for realizing industrial application of this potential and sustainable technology.

Side-chain alkylation of toluene requires the catalysts possessing base sites to activate the carbon atom of the methyl group in toluene and to dehydrogenate methanol to

${ }^{a}$ State Key Laboratory of Fine Chemicals, School of Chemical Engineering, Dalian University of Technology, Dalian 116024, People's Republic of China. E-mail: hongchenguo@dlut.edu.cn

${ }^{b}$ National Laboratory for Clean Energy, Dalian Institute of Chemical Physics, Chinese Academy of Sciences, Dalian 116023, People's Republic of China. E-mail: leixu@dicp. ac.cn

'University of Chinese Academy of Sciences, Beijing 100049, People's Republic of China $\dagger$ Electronic supplementary information (ESI) available. See DOI: $10.1039 / \mathrm{c} 9 \mathrm{ra} 01798 \mathrm{~d}$ formaldehyde which acts as the actual alkylating reagent, and the suitable base properties of catalysts are the key point for efficient conversion of toluene to styrene. ${ }^{4-6}$ Base faujasite zeolite (X or Y), which can be obtained through exchanging the hydrogen proton of the parent zeolite with alkali metal ions $\left(\mathrm{Li}^{+}\right.$, $\mathrm{Na}^{+}, \mathrm{K}^{+}, \mathrm{Ru}^{+}, \mathrm{Cs}^{+}$), is generally regarded as a potential catalyst for side-chain alkylation of toluene with methanol..$^{7-9}$ The alkali cations act as Lewis acid sites and the oxygen atoms with negative charge $\left(\mathrm{O}^{\delta-}\right)$ in the zeolite framework act as Lewis base sites. $^{10-12}$ According to a current consensus, cesium ion exchanged zeolite $\mathrm{X}(\mathrm{CsX})$ is the most promising catalyst for side-chain alkylation of toluene with methanol. ${ }^{2,4,13}$ It was found that further modifying CsX with cesium oxide can greatly improve its catalytic activity for side-chain alkylation of toluene with methanol. ${ }^{5,8,14,15}$ Archier et al. found that modifying CsX with cesium oxides can promote the side-chain alkylation of toluene with methanol, and suggested it was attributed to the promotion for the generation of formaldehyde from methanol on the alkali oxides particles. ${ }^{15}$ And Han et al. gave a similar speculation after study of side-chain alkylation of toluene with methanol over KX or CsX modified with potassium oxide or cesium oxide. ${ }^{8}$ However, Alabi et al. thought that the generation of new strong basic sites was helpful in activating the methyl group of toluene, which was responsible for the promotion effect. ${ }^{5}$ As mentioned above, the introduction of alkali oxides 
can promote the side-chain alkylation of toluene with methanol, but its promotion mechanism is still controversial, and few studies are carried out to investigate the concrete effects on side-chain alkylation of toluene with methanol through varying the base properties of the alkali oxides modified CsX.

It is widely accepted that modifying alkali ion exchanged zeolite with alkali oxides can greatly improve its base properties which is owing to the introduction of strong base sites. ${ }^{\mathbf{1 0 , 1 6 - 1 8}}$ Davis et al. found that modified CsX with cesium oxide exhibited higher $\mathrm{CO}_{2}$ adsorption capacities and higher heats than the parent zeolite, but the adsorption heats was significantly lower than bulk cesium oxide. ${ }^{\mathbf{1 9 0}}$ They perceived that the cesium oxide loaded in the zeolite was not stoichiometric oxides, and the $\mathrm{Cs}-\mathrm{O}$ bond in the loaded cesium oxides was more ionic than in the bulk-phase. ${ }^{\mathbf{1 0 , 1 1}}$ Regarding the introduced base sites in alkali oxides modified zeolite, Hattori et al. considered that the alkali oxides located in the zeolite cavities were the introduced strong base sites which accounted for the promotion of 1butene isomerization. ${ }^{21,22}$ Hunger et al. confirmed the existence of strong base sites on the guest alkali oxides by ${ }^{13} \mathrm{C} \mathrm{CP} / \mathrm{MAS}$ NMR with methyl iodide as a probe, and found that the chemical bonds of the parent zeolite can be affected by the loaded cesium oxide which would lead to the enhancement of base strength of $\mathrm{O}^{\delta-}$ in the host zeolite framework. ${ }^{23,24}$ It can be found that the promoting effects for base properties of the base zeolite by further modification with alkali oxides were investigated widely. However, scarce attentions have been given to the correlation of the introduced base sites in alkali oxides modified CsX with the promotion for side-chain alkylation of toluene with methanol, especially for the mechanism understanding.

We recently discovered that side-chain alkylation of toluene with methanol is extraordinarily sensitive to the base properties of the catalysts. ${ }^{4}$ The investigation of the effects on side-chain alkylation of toluene with methanol by the introduced base sites in alkali oxides modified CsX will be of great importance to interpret the promoting effect for side-chain alkylation reaction over CsX by modification with alkali oxides.

In the present work, we further studied the influence of base properties gradient of the alkali oxides modified CsX and the type of introduced base sites to side-chain alkylation of toluene with methanol. A series of alkali oxides modified CsX with base properties gradient were prepared by the impregnation of CsX with indicated alkali metal hydroxide: CsX modified with different cesium oxide loading amount, with different kinds of alkali oxide; and CsX with different base strength (different cesium ion exchange degree) modified with same cesium oxide loading amount. And pure silica zeolite $\beta$, modified with cesium oxide, was also prepared as the comparison sample. The base properties of the catalyst samples were characterized by temperature-program desorption of $\mathrm{CO}_{2}\left(\mathrm{CO}_{2}\right.$-TPD), XPS and FT-IR of adsorbed $\mathrm{CO}_{2}$. Furthermore, detailed analysis of the correlation between the reaction behaviors of side-chain alkylation of toluene with methanol and the base properties and base site type of the indicated catalysts was carried out. Base on above studies, the promoting reasons for side-chain alkylation of toluene with methanol by modifying CsX with alkali oxides was figured out, and the cause for the aggravated conversion of styrene to ethylbenzene in the products over the alkali oxides modified CsX was also revealed.

\section{Experimental}

\subsection{Catalyst preparation}

Zeolite $\mathrm{NaX}$ (Catalyst Plant of Nankai University, $\mathrm{Si} / \mathrm{Al}=1.2$ ) was ion-exchanged with aqueous solutions of cesium chloride (Aladdin, 99\%) to prepare CsX. CsX-1, CsX-2 and CsX-4 with exchange degrees of $21.8 \%, 32.3 \%$ and $45.9 \%$ shown in our preceding paper were chosen as the parent zeolites, which is denoted as CsX- $a$, CsX- $b$ and CsX- $c$ respectively in this work. ${ }^{4}$ And the $\mathrm{XRD}, \mathrm{CO}_{2}$-TPD and catalytic activity for reaction between toluene and methanol of them were also taken from our preceding work. The pure silica zeolite $\beta$ was synthesized according to the reported procedure. ${ }^{25}$

The alkali oxides modified CsX were prepared by incipient wetness impregnation of CsX with alkali metal hydroxides aqueous solutions at room temperature. After addition of impregnation precursor solution, the mixtures were stood in ceramic crucible for $12 \mathrm{~h}$ at room temperature, followed by drying at $110{ }^{\circ} \mathrm{C}$ for $4 \mathrm{~h}$, and then calcined at $550{ }^{\circ} \mathrm{C}$ in air atmosphere for $4 \mathrm{~h}$. The loaded amount of alkali oxides was adjusted by the concentration of alkali metal hydroxides in the aqueous solutions. The alkali oxides supported on the zeolite were denoted as MOx ( $\mathrm{M}$ represents $\mathrm{Na}, \mathrm{K}$ or $\mathrm{Cs}$ ) after calcination. And the catalysts were named as $A \mathrm{MOx} / \mathrm{CsX}-B$, where $A$ and $B$ referred to the alkali oxides amount and the code for CsX with different cesium ion exchange degree, respectively. For example, $8 \mathrm{CsOx} / \mathrm{CsX}-c$ was $\mathrm{CsX}-c$ loaded with $8 \mathrm{CsOx}$ per unit cell. Similarly, $1.72 \mathrm{CsOx} / \beta$ was prepared by the same method, which had the same loading weight as $8 \mathrm{CsOx} / \mathrm{CsX}-c$.

\subsection{Catalyst characterization}

Powder X-ray diffraction (XRD) patterns were obtained on a PANalytical X'Pert PRO X-ray diffractometer with $\mathrm{Cu} \mathrm{K} \alpha$ radiation, operating at $40 \mathrm{kV}$ and $40 \mathrm{~mA}$. The patterns were recorded in the $2 \theta$ range of 5 to $50^{\circ}$.

The compositions of the samples were measured by X-ray fluorescence (XRF) spectroscopy with a Philips Magix-601 Xray fluorescence spectrometer.

$\mathrm{N}_{2}$ adsorption-desorption isotherms were measured at $-196{ }^{\circ} \mathrm{C}$ on a Quantachrome Autosorb iQ2 physical adsorption analyzer system after the samples were outgassed in vacuum for $10 \mathrm{~h}$ at $300{ }^{\circ} \mathrm{C}$.

Temperature-program desorption (TPD) of adsorbed $\mathrm{CO}_{2}$ and $\mathrm{NH}_{3}$ were performed on Micromeritics Autochem 2920. After the sample was pretreated in helium stream at $550{ }^{\circ} \mathrm{C}$ for $1.5 \mathrm{~h}$ and cooled down to $80{ }^{\circ} \mathrm{C}\left(100{ }^{\circ} \mathrm{C}\right.$ for $\mathrm{NH}_{3}$-TPD $)$, it was exposed to pure $\mathrm{CO}_{2}$ or $8 \% \mathrm{NH}_{3} / \mathrm{He}$ (vol/vol) for $30 \mathrm{~min}$ and swept with helium at a flow rate of $30 \mathrm{~mL} \mathrm{m^{-1 }}$ (STP) for $30 \mathrm{~min}$, then, the temperature elevated at a rate of $10^{\circ} \mathrm{C} \mathrm{min}{ }^{-1}$. For the $\mathrm{CO}_{2}$-TPD, a cold trap $\left(-47^{\circ} \mathrm{C}\right)$ with a mixture of liquid nitrogen and $m$-xylene was installed to avoid errors caused by water in thermal conductivity detector (TCD). 
X-ray photoelectron spectroscopy (XPS) measurements were performed on Thermo Fisher ESCALAB 250Xi, and the based pressure was $1 \times 10^{-8} \mathrm{~Pa}$. An $\mathrm{Al} \mathrm{K} \alpha$ radiation $(h \nu=1486.6 \mathrm{eV})$ was used as the X-ray source, and operated at $15 \mathrm{kV}$ and 10.8 $\mathrm{mA}$. The $\mathrm{C} 1 \mathrm{~s}$ peak at $284.6 \mathrm{eV}$ in the background was used as the reference energy for the binding energy calibration.

Fourier transform infrared (FT-IR) spectra of adsorbed $\mathrm{CO}_{2}$ and $\mathrm{NH}_{3}$ were recorded at a spectral resolution of $4 \mathrm{~cm}^{-1}$ on Bruker Tensor 27 instrument. The samples was pressed into a self-supporting wafer $(10 \mathrm{mg}, R=0.65 \mathrm{~cm})$, and placed in an in situ quartz IR cell with $\mathrm{KBr}$ windows. After pretreatment under vacuum $\left(10^{-2} \mathrm{~Pa}\right)$ for $2 \mathrm{~h}$ at $500{ }^{\circ} \mathrm{C}\left(450{ }^{\circ} \mathrm{C}\right.$ for FT-IR of adsorbed $\mathrm{NH}_{3}$ ), the sample was exposed to $650 \mathrm{~Pa} \mathrm{CO}_{2}$ at $80{ }^{\circ} \mathrm{C}$ or $8 \% \mathrm{NH}_{3} /$ $\mathrm{He}(\mathrm{vol} / \mathrm{vol})$ at $100^{\circ} \mathrm{C}$ for $30 \mathrm{~min}$. For the FT-IR of adsorbed $\mathrm{CO}_{2}$, the samples was then swept with $40 \mathrm{~mL} \mathrm{~min}{ }^{-1} \mathrm{~N}_{2}$ (STP) at the indicated temperature for $30 \mathrm{~min}$. And for FT-IR of adsorbed $\mathrm{NH}_{3}$, the samples were evacuated under vacuum $\left(10^{-2} \mathrm{~Pa}\right)$ at $100^{\circ} \mathrm{C}$ for $30 \mathrm{~min}$. All the spectra for FT-IR of adsorbed $\mathrm{CO}_{2}$ were recorded at $80{ }^{\circ} \mathrm{C}$, and $100{ }^{\circ} \mathrm{C}$ for FT-IR of adsorbed $\mathrm{NH}_{3}$.

\subsection{Catalyst testing}

$1.0 \mathrm{~g}$ of the catalysts (20-40 mesh) was used in the catalyst testing on a fixed bed reactor (quartz, $9 \mathrm{~mm}$ i.d.). The samples were activated under a flow of air $\left(40 \mathrm{~mL} \mathrm{~min}^{-1}\right)$ for $1.5 \mathrm{~h}$ at $550^{\circ} \mathrm{C}$. After the sample was cooled to the reaction temperature of $430{ }^{\circ} \mathrm{C}$ and swept with helium for $30 \mathrm{~min}$ at a flow rate of 40 $\mathrm{mL} \min ^{-1}$ (STP), a liquid mixture of toluene and methanol (molar ratio of $1: 2$ ) was fed into the reactor by a ram pump at a weight hourly space velocity (WHSV) of $2 \mathrm{~h}^{-1}$ with helium at a flow rate of $10 \mathrm{~mL} \mathrm{~min}^{-1}$ (STP). For investigating the influence for catalytic activity of $8 \mathrm{CsOx} / \mathrm{CsX}-c$ by pretreating with $\mathrm{CO}_{2}, 40$ $\mathrm{mL} \min ^{-1}$ (STP) $\mathrm{CO}_{2}$ was given at $80{ }^{\circ} \mathrm{C}$ for $30 \mathrm{~min}$, and then swept the catalysts with $40 \mathrm{~mL} \mathrm{~min}^{-1}$ (STP) helium for $30 \mathrm{~min}$ at $400{ }^{\circ} \mathrm{C}$ before introducing the reactants.

An on-line gas chromatograph (Agilent GC7890A) was used for the analysis of products. Hydrocarbons, methanol and dimethyl ether were analyzed by a flame ionization detector (FID) with Agilent CP-WAX $(25 \mathrm{~m} \times 32 \mu \mathrm{m} \times 1.2 \mu \mathrm{m})$ capillary column, and $\mathrm{CO}, \mathrm{CO}_{2}$ and formaldehyde was analyzed by thermal conductivity detector (TCD) with a Porapak Q $(4 \mathrm{~m} \times 1 /$ $\left.8^{\prime \prime}\right)$ packed column, the activity results are presented as conversion of methanol $\left(X_{\text {methanol }}\right)$, toluene $\left(X_{\text {toluene }}\right)$, yield of styrene and ethylbenzene $\left(Y_{\mathrm{ST}+\mathrm{EB}}\right)$, xylene $\left(Y_{\text {xylene }}\right), \mathrm{CO}$ and $\mathrm{CO}_{2}$ $\left(Y_{\mathrm{CO}+\mathrm{CO}_{2}}\right)$ and molar ratio of styrene to ethylbenzene in products (ST/EB), which are defined as follows (quantities are molar flow rates):

$$
\begin{aligned}
& X_{\text {methanol }}=\frac{\text { methanol }_{\text {inlet }}-\text { methanol and } \mathrm{DME}_{\text {outlet }}}{\text { methanol }_{\text {inlet }}} \times 100 \% \\
& X_{\text {toluene }}=\frac{\text { toluene }_{\text {inlet }}-\text { toluene }_{\text {outlet }}}{\text { toluene }_{\text {inlet }}} \times 100 \% \\
& Y_{\mathrm{ST}+\mathrm{EB}}=\frac{\text { styrene }_{\text {outlet }}+\text { ethylbezene }_{\text {outlet }}}{\text { toluene }_{\text {inlet }}} \times 100 \%
\end{aligned}
$$

$$
\begin{gathered}
Y_{\text {xylene }}=\frac{\text { xylene }_{\text {outlet }}}{\text { toluene }_{\text {inlet }}} \times 100 \% \\
Y_{\mathrm{CO}+\mathrm{CO}_{2}}=\frac{\mathrm{CO}_{\text {outlet }}+\mathrm{CO}_{2 \text { outlet }}}{\text { methanol } \text { inlet }_{\text {f }}} \times 100 \% \\
\mathrm{ST} / \mathrm{EB}=\frac{\text { styrene }_{\text {outlet }}}{\text { ethylbenzene }_{\text {outlet }}}
\end{gathered}
$$

All data were obtained at the reaction time of $50 \mathrm{~min}$.

\section{Results and discussion}

\subsection{Structural and physicochemical characteristics of the catalysts}

The structural and physicochemical characteristics of the CsX$a, \mathrm{CsX}-b$ and CsX-c (exchange degrees were 21.8\%, 32.3\% and $45.9 \%$, respectively) have been displayed and analyzed in our previous work. ${ }^{4}$ The XRD patterns and composition of all the CsX modified with alkali oxides are presented in Fig. 1 and Table S2. $\dagger$ As shown in Fig. 1, all the modified CsX samples clearly showed typical peaks of zeolite $\mathrm{X}$ structure, and characteristic diffraction patterns of zeolite- $\beta$ were obtained over pure silica zeolite $\beta$ before and after loading cesium oxide, indicating the zeolite structures were retained after modifying with alkali oxides. However, the relative peak intensities of all the modified zeolites were reduced with the introduction of alkali oxides. Romero et al. found that there was no resonance shift of the ${ }^{29} \mathrm{Si}$ MAS NMR signals before and after the modification of zeolite $\mathrm{X}$ with cesium oxide and no extra-framework aluminum was detected by ${ }^{27} \mathrm{Al}$ MAS NMR spectrum after the modification, although the XRD pattern of the zeolite X reduced sharply after

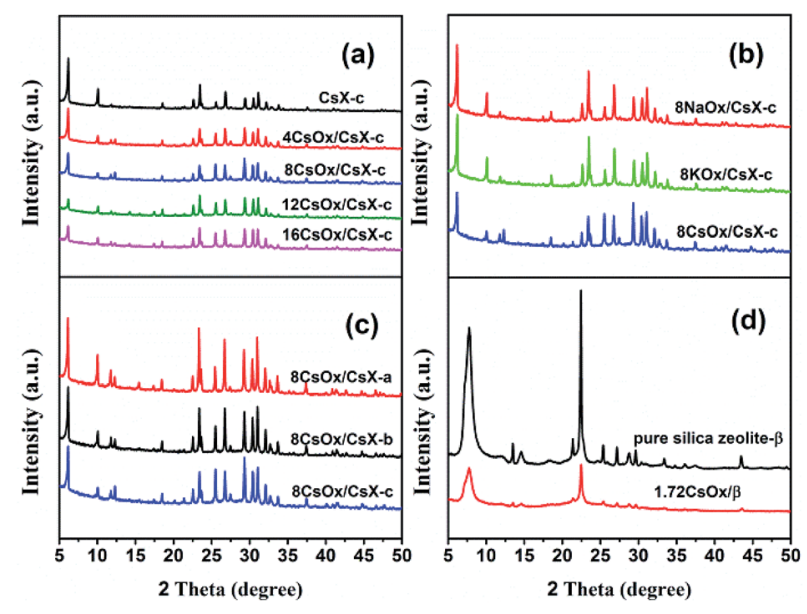

Fig. 1 XRD patterns of the indicated catalysts (a) CsX-c loaded with different cesium oxide amount; (b) CsX-c loaded with different kinds of alkali oxides; (c) CsX with different cesium ion exchange degree loaded with $8 \mathrm{CsOx}$ per unit cell; (d) pure silica zeolite- $\beta$ before and after loading cesium oxide. 
the modification. ${ }^{\mathbf{1 6}}$ Thereof, the reduction of the XRD relative peak intensities of the modified CsX might be mainly attributed to the change of X-ray absorption behavior with the introduction of alkali oxide rather than the collapse of the zeolite framework..$^{8,26,27}$

The textural properties of CsX-c with different cesium oxide amounts are displayed in Table $\mathrm{S} 1 \dagger$ and the BET surface area $\left(S_{\mathrm{BET}}\right)$ and micropore volume $\left(V_{\text {micro }}\right)$ of CsX-c decreased after introduction of the cesium oxide. According to current knowledge, the cesium oxide is located primarily in the supercages of CsX when the loaded cesium atoms content is less than 24 cesium atoms per unit cell. ${ }^{26,28}$ The maximum loading amount of $\mathrm{CsOx}$ in present work is 16 cesium atoms per unit cell, suggesting the cesium oxide is mainly in the pore of CsX. Therefore, the decrease of BET surface area and micropore volume might be attributed to the occupation of the available void volume by the loaded cesium oxide. What is more, the decrease of the micropore volume as a function of the loaded cesium oxide amount is almost a straight line (Fig. S1 $\dagger$ ), indicating that there is almost no obvious collapse of the zeolite structure after modifying with cesium oxide. ${ }^{29}$

\subsection{Characterization and analysis of base properties of the alkali oxides modified CsX}

$\mathrm{CO}_{2}$-TPD curves for all the catalysts are shown in Fig. 2, from which it can be seen that all the $\mathrm{CO}_{2}$ desorption peaks appeared below $400{ }^{\circ} \mathrm{C}$. And both the $\mathrm{CO}_{2}$ desorption temperature and area increased when the CsX was modified with alkali oxides, indicating that stronger base sites were introduced. And the $\mathrm{CO}_{2}$ desorption temperature of the alkali oxides modified CsX increased with the increase of the alkali oxides loaded amount and the increase of the atomic number of the alkali metal in the loaded alkali oxides as well as the initial base strength of the parent zeolite. Moreover, it should be noticed that a gradual uptrend is observed at temperature higher than $500{ }^{\circ} \mathrm{C}$ over
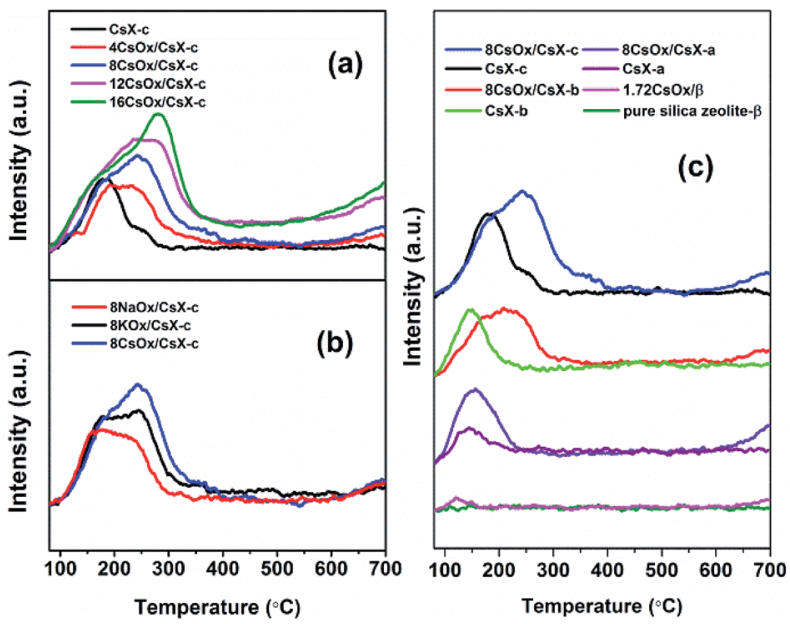

Fig. $2 \mathrm{CO}_{2}$-TPD curves of the indicated catalysts (a) CsX-c loaded with different cesium oxide amount; (b) CsX-c loaded with different kinds of alkali oxides; (c) different zeolite parents before and after loading cesium oxide. alkali oxides modified zeolite, especially for samples with high loading amount.

Two kinds of base sites could be introduced when base zeolite was modified with cesium oxide: the strong base sites created on cesium oxide and the base strength enhanced oxygen atoms with negative charge $\left(\mathrm{O}^{\delta-}\right)$ in the zeolite framework. ${ }^{24}$ As shown in Fig. 2(c), the $\mathrm{CO}_{2}$ desorption temperature of the cesium oxide modified CsX modified with same cesium oxide amount increased with the base strength of their parent CsX strengthened, which finds difficulty to understand when it comes to explain these introduced base sites created on the cesium oxides. That is to say if these introduced strong base sites is created by the cesium oxide itself, a similar $\mathrm{CO}_{2}$ desorption peak at high temperature should be detected for all the modified zeolite with same cesium oxide amount in Fig. 2(c) instead of relating closely with the desorption temperature of their parent CsX. Thus, it is suggested that the introduced base sites which correspond to the $\mathrm{CO}_{2}$ desorption below $400{ }^{\circ} \mathrm{C}$ may be caused by the base strength enhanced $\mathrm{O}^{\delta-}$ in the CsX framework.

To further confirm this speculation, the base properties of cesium oxide modified pure silica zeolite $\beta$ were investigated considering that both of zeolite $\beta$ and zeolite $X$ have three dimensional 12-membered ring pore structure. As shown in Fig. 2(c), there was no $\mathrm{CO}_{2}$ desorption peak on pure silica zeolite $\beta$ and only a small peak can be detected at $118{ }^{\circ} \mathrm{C}$ on cesium oxide modified zeolite $\beta$, which may be attributed to the effects on defective sites of the zeolite by cesium oxide. For the CsX, the base sites are the oxygen atoms with negative charge $\left(\mathrm{O}^{\delta-}\right)$ in the zeolite framework and the base properties could be enhanced with increase of the cesium ion exchange degree. ${ }^{4,30}$ This base sites cannot be generated over pure silica zeolite due to lack of $\mathrm{O}^{\delta-}$ in the framework as $\mathrm{O}^{\delta-}$ only present in the framework of zeolite possessing the $\mathrm{Si}-\mathrm{O}-\mathrm{Al}$ species. ${ }^{17}$ This result also suggested that the introduced base sites which correspond to the $\mathrm{CO}_{2}$ desorption below $400{ }^{\circ} \mathrm{C}$ should be attributed to the increased base strength of $\mathrm{O}^{\delta-}$ in zeolite framework of CsX, and the $\mathrm{CO}_{2}$ adsorbed on strong base sites created by alkali oxides was desorbed over $500{ }^{\circ} \mathrm{C}$.

In order to investigate the existence state of the adsorbed $\mathrm{CO}_{2}$ in the zeolite, the FT-IR spectra of the adsorbed $\mathrm{CO}_{2}$ on $\mathrm{CsX}-c, 8 \mathrm{CsOx} / \mathrm{CsX}-c$ and $16 \mathrm{CsOx} / \mathrm{CsX}-c$ were measured, and the results are shown in Fig. 3. A pair of strong bands at $1648 \mathrm{~cm}^{-1}$ and $1385 \mathrm{~cm}^{-1}$ was detected on CsX-c after adsorbing $\mathrm{CO}_{2}$, which can be ascribed to asymmetric stretching bands and symmetric stretching bands of bidentate carbonate, respectively. ${ }^{5,13}$ As is shown in Fig. 3, the samples of $8 \mathrm{CsOx} / \mathrm{CsX}-c$, 16CsOx/CsX- $c$ and CsX- $c$ revealed similar $\mathrm{CO}_{2}$ absorption bands. And after sweeping with $\mathrm{N}_{2}$ at $300{ }^{\circ} \mathrm{C}$ for CsX-c and $400{ }^{\circ} \mathrm{C}$ for $8 \mathrm{CsOx} / \mathrm{CsX}-c$ and $16 \mathrm{CsOx} / \mathrm{CsX}-c$, all the absorption bands disappeared. Combined the results of the $\mathrm{CO}_{2}$-TPD in Fig. 2, it can be concluded that those absorption bands are corresponding to the $\mathrm{CO}_{2}$ desorption peaks in the $\mathrm{CO}_{2}$-TPD in Fig. 2 below $400{ }^{\circ} \mathrm{C}$. It can be found that the bands for bidentate carbonate decreased with the sweeping temperature increased, and its stability on the cesium oxide modified CsX-c increased with the increasing loading amount, which is consistent with the 


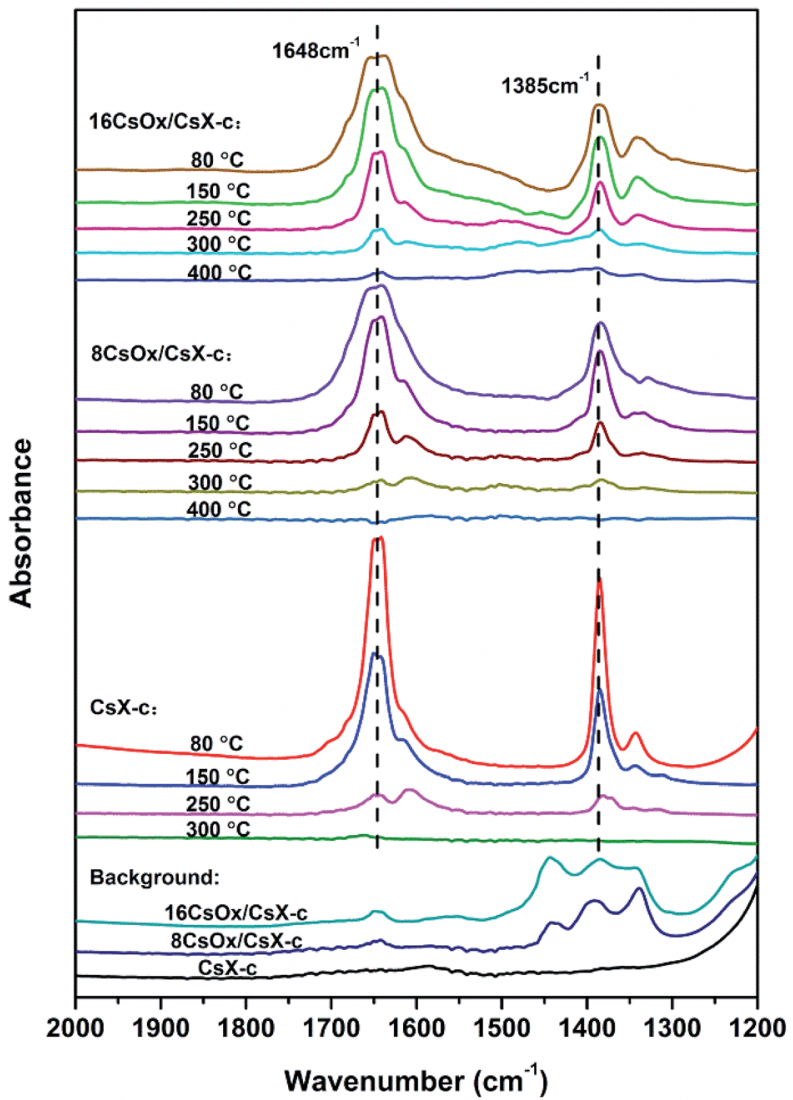

Fig. 3 FT-IR spectra of adsorbed $\mathrm{CO}_{2}$ on $\mathrm{CsX}-\mathrm{C}, 8 \mathrm{CsOx} / \mathrm{CsX}-\mathrm{C}$ and $16 \mathrm{CsO} / \mathrm{CsX}-\mathrm{c}$. The backgrounds were recorded after the samples were pretreated at $500{ }^{\circ} \mathrm{C}$ in vacuum for $2 \mathrm{~h}$, after adsorbing $\mathrm{CO}_{2}$ at $80{ }^{\circ} \mathrm{C}$, the samples were further swept with $\mathrm{N}_{2}$ at the indicated temperature for $30 \mathrm{~min}$. All the spectra were recorded at $80^{\circ} \mathrm{C}$ and the

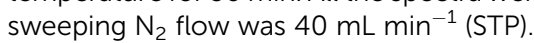

increase of $\mathrm{CO}_{2}$ desorption temperature in $\mathrm{CO}_{2}$-TPD after alkali oxides modification.

Additionally, no absorption band was detected on the CsX-c after pretreated at $500{ }^{\circ} \mathrm{C}$, while three peaks appeared in the region of $1300-1500 \mathrm{~cm}^{-1}$ on $8 \mathrm{CsOx} / \mathrm{CsX}-c$, which should be responsible for the uptrend after $500{ }^{\circ} \mathrm{C}$ in the $\mathrm{CO}_{2}$-TPD shown in Fig. 2. Absorption bands was also found in this region in the work of Alabi et al., which was ascribed to the formation of ionic carbonate and unidentate carbonate on cesium oxide by adsorbing $\mathrm{CO}_{2}{ }^{5}$ Unidentate carbonate is generally formed on strong base sites by adsorbing $\mathrm{CO}_{2}$, and it is inherent before the introduction of $\mathrm{CO}_{2}$ during the experimental process, suggesting that the adsorbed $\mathrm{CO}_{2}$ on the strong base sites of cesium oxide itself was from the air and could not be removed by pretreatment at $500{ }^{\circ} \mathrm{C}$.

XPS studies were carried out to investigate the influence of the loaded alkali oxides on the framework of CsX, and the results are shown in Fig. 4 . It has been widely accepted that $S_{\text {int }}$ (Sanderson intermediate electronegativity) of the zeolite is related to the acid-base properties of zeolite, and the lower $S_{\text {int }}$ of the base zeolite, the higher the base strength. ${ }^{31-35}$ For alkali cation exchanged zeolite, the lower binding energy (BE) of Si $2 p$

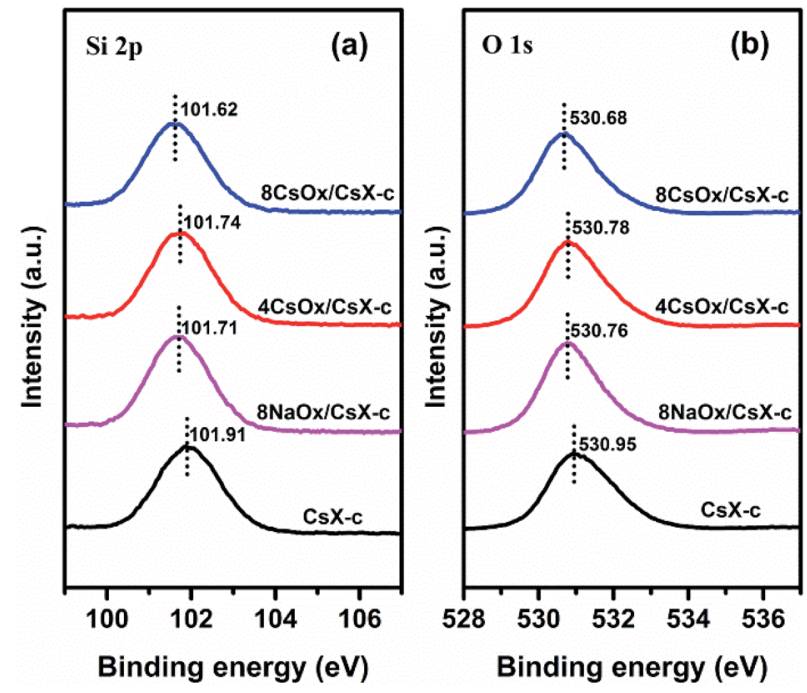

Fig. 4 XPS spectra of the indicated catalysts: (a) spectra of Si 2p; (b) spectra of $O 1 \mathrm{~s}$.

and O 1s means lower $S_{\mathrm{int}}{ }^{36,37}$ It can be seen that the BE of Si 2p and $\mathrm{O} 1 \mathrm{~s}$ decreases after loading alkali oxides, indicating that the base strength of the $\mathrm{O}^{\delta-}$ in the zeolite framework was promoted by the loaded alkali oxides. This result clearly demonstrates the chemical interaction imposed zeolite framework by the loaded alkali oxides. ${ }^{38}$

According to the principle of Sanderson electronegativity equalization, different atoms will be adjusted to the same electronegativity within the compound when they are combined chemically, and $S_{\text {int }}$ is the geometric mean value of electronegativity of the compound. ${ }^{31}$ Assuming the abundant existing state of alkali oxides in the CsX is in formula of $\mathrm{M}_{2} \mathrm{O}$ (where $\mathrm{M}$ is $\mathrm{Na}, \mathrm{K}$ and $\mathrm{Cs}$ ), when alkali oxides insert into the CsX by chemical combination, the electronegativity of $\mathrm{M}_{2} \mathrm{O}$ and CsX will reach a new equilibrium value according to the principle of Sanderson electronegativity equalization, and the negative charge will transfer to the framework of CsX from alkali oxides as the $S_{\text {int }}$ for CsX is higher than that of $\mathrm{M}_{2} \mathrm{O}$ (Table S2 $\dagger$ ). ${ }^{39}$ Hence, the electron donating function of the loaded alkali oxides for the zeolite framework should be the intrinsic reason for the promotion of base strength of the $\mathrm{O}^{\delta-}$ in the zeolite framework. What is more, the $\mathrm{BE}$ of $\mathrm{Si} 2 \mathrm{p}$ and $\mathrm{O} 1 \mathrm{~s}$ decreases in the order of $\mathrm{CsX}-c>4 \mathrm{CsOx} / \mathrm{CsX}-c>8 \mathrm{NaOx} / \mathrm{CsX}-c>8 \mathrm{CsOx} / \mathrm{CsX}-c$, indicating that the electron donating function for the framework of CsX increases with increasing alkali oxides loading amount and atomic number of alkali metal in the alkali oxides. The increase of atomic number of the alkali metal means the decrease of its metallicity which will lead to the increase of the electron donating ability of its oxide. Meanwhile, it can be found that the increasing trend of the $\mathrm{CO}_{2}$ desorption temperature for CsX modified with different cesium loading amount and different kinds of alkali oxides according well to the above electron donating regularities (Fig. 2(a) and (b)).

Moreover, it should be noticed that the area of desorption peak in $\mathrm{CO}_{2}$-TPD increases when $\mathrm{CsX}$ is modified by alkali oxides. The $\mathrm{CO}_{2}$ desorption amount and the amount of $\mathrm{O}^{\delta-}$ in the zeolite framework are listed in Table S2. $\dagger$ The amount of 
$\mathrm{O}^{\delta-}$ in the zeolite framework is far more than that of the desorbed $\mathrm{CO}_{2}$, suggesting that only part of the $\mathrm{O}^{\delta-}$ sites with strong enough base strength in the zeolite framework could adsorb $\mathrm{CO}_{2}$. When the CsX was modified with alkali oxide, the base strength of $\mathrm{O}^{\delta-}$ would be enhanced so that more $\mathrm{O}^{\delta-}$ sites would have enough base strength to adsorb $\mathrm{CO}_{2}$.

\subsection{Analysis and discussion for side-chain alkylation of toluene with methanol over alkali oxides modified CsX}

3.3.1. The promotion for side-chain alkylation of toluene with methanol over the alkali oxides modified CsX. The reaction behaviors of side chain alkylation of toluene with methanol over all the catalysts are shown in Fig. 5 and Table S3. $\dagger$ There is almost no styrene and ethylbenzene produced over pure silica $\beta$ and $1.72 \mathrm{CsOx} / \beta$ (Table S3 $\uparrow$ ). And as shown in Fig. $5(\mathrm{a})$, adding $1.72 \mathrm{CsOx} / \beta$ to $\mathrm{CsX}-c$ by mechanical or grinding mixture has little influence on the $Y_{\mathrm{ST}+\mathrm{EB}}$ and ST/EB over CsX-c. However, compared to CsX-c, a sharply increased and decreased trend is observed for $Y_{\mathrm{ST}+\mathrm{EB}}$ and ST/EB over 4CsOx/CsX-c, respectively, which is a sign of base properties enhancement of the base zeolite. ${ }^{4}$ Thus, it suggested that the cesium oxide itself has no effects on side-chain alkylation of toluene with methanol, and the promotion for side-chain alkylation of toluene over the alkali oxides modified CsX should be attributed to the increase of base properties of CsX.

During the reaction process of side-chain alkylation of toluene with methanol, formaldehyde is generated by dehydrogenation of methanol over the base sites of CsX, and it is widely accepted that the generated formaldehyde acts as the actual alkylating reagent for side-chain alkylation of toluene. ${ }^{1,6,40}$ Meanwhile, a part of the generated formaldehyde that has not reacted with the activated toluene will further decompose to $\mathrm{CO}$ over the base sites, ${ }^{\mathbf{1 4 , 4 1}}$ and small part of the formed $\mathrm{CO}$ will be further converted into $\mathrm{CO}_{2} \cdot{ }^{13}$ In previous work, we have proved that the dehydrogenation of methanol to formaldehyde, which can be promoted by increasing both the base strength and amount of the base sites, is the crucial step for side-chain alkylation of toluene with methanol over CsX with cesium exchange degree higher than $32.3 \%{ }^{4}$ Thus, improving the base properties of CsX will promote the conversion of methanol, the formation of styrene and ethylbenzene and the yield of $\mathrm{CO}$ and $\mathrm{CO}_{2}$. In addition to the base sites, the acid sites are also required for side-chain alkylation of toluene with methanol, which play a role in adsorbing and stabilizing the benzene ring of toluene. ${ }^{41}$ In our previous work, it was confirmed that the existence of Brønsted acid sites would lead to the production of xylene, and Lewis acid sites derived from the positive ions in CsX are the essential acid sites involved in
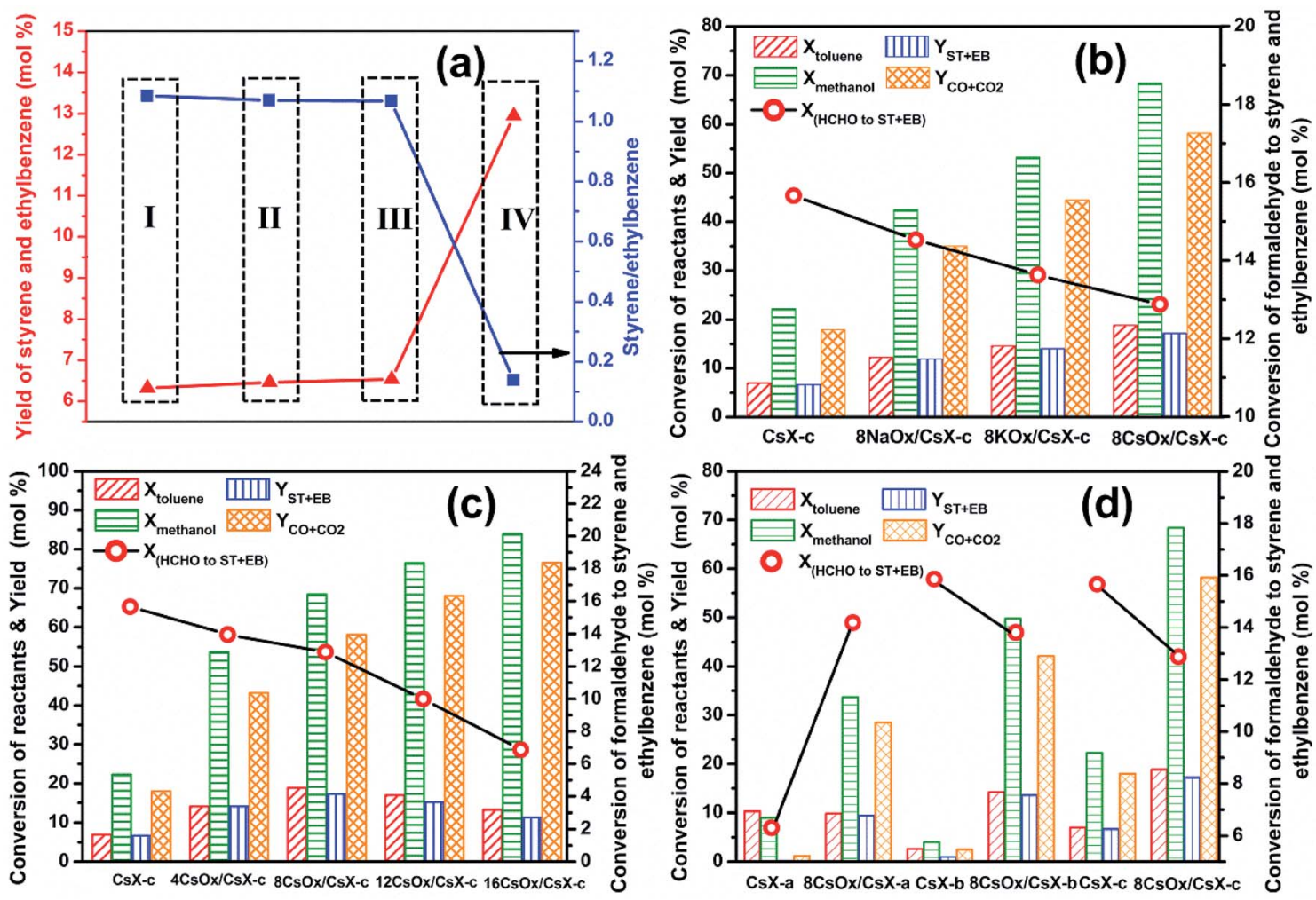

Fig. 5 The reaction behaviors of side-chain alkylation of toluene with methanol over the indicated catalysts (a) I: CsX-c (20-40 mesh) mechanically mixed with pure silica zeolite $\beta$ (20-40 mesh), II: CsX-c (20-40 mesh) mechanically mixed with 1.72CsOx/ $\beta$ (20-40 mesh), III: CsX$c$ mixed with $1.72 \mathrm{CsO} / \beta$ by grinding in a mortar for $10 \mathrm{~min}, \mathrm{IV}: 4 \mathrm{CsOx} / \mathrm{CsX}-c$ (20-40 mesh) mechanically mixed with pure silica $\beta$ (20-40 mesh), the mass ratio of $\mathrm{CsX}-\mathrm{c}$ or $4 \mathrm{CsOx} / \mathrm{CsX}-\mathrm{c}$ to pure silica zeolite $\beta$ or $1.72 \mathrm{CsOx} / \beta$ was $2: 1$; (b) $\mathrm{CsX}-c$ loaded with different kinds of alkali oxides; (c) CsX-c loaded with different cesium oxide amount; (d) same cesium oxide amount loaded in CsX with different cesium exchange degree. The calculation of $Y_{\mathrm{ST}+\mathrm{EB}}$ was calculated based on the inlet quantities of toluene, and $Y_{\mathrm{CO}+\mathrm{CO}_{2}}$ was based on the inlet quantities of methanol. 
side-chain alkylation of toluene. ${ }^{4}$ As shown in Fig. S2, $\dagger$ no acid site is introduced by the introduction of alkali oxides, and the Lewis acid sites in CsX are little influenced by modifying with alkali oxides. Thus, the major influence for side-chain alkylation of toluene with methanol over the alkali oxides modified CsX in Fig. 5 should be the changes of base properties of the catalysts.

The reaction behaviors of side-chain alkylation of toluene with methanol over CsX-c modified with different kinds of alkali oxides are shown Fig. 5(b). After the CsX-c was modified with alkali oxides, the $X_{\text {toluene }}, X_{\text {methanol }}, Y_{\mathrm{ST}+\mathrm{EB}}$ and $Y_{\mathrm{CO}+\mathrm{CO}_{2}}$ increased in the order of $8 \mathrm{NaOx} / \mathrm{CsX}-c<8 \mathrm{KOx} / \mathrm{CsX}-c<8 \mathrm{CsOx} / \mathrm{CsX}-c$. This is in consistent with the change in the base strength and base sites amount of the three catalysts (Fig. 2(b) and Table S2†), indicating that the introduced base sites in alkali oxides modified CsX promoted the side-chain alkylation of toluene with methanol. The influence for side-chain alkylation of toluene with methanol by with or without $\mathrm{CO}_{2}$ pretreatment for $8 \mathrm{CsOx} / \mathrm{CsX}-c$ was shown in Table 1 . It can be seen that pretreating $8 \mathrm{CsOx} /$ CsX- $c$ with $\mathrm{CO}_{2}$ has litter influence on $X_{\text {toluene }}, X_{\text {methanol }}, Y_{\mathrm{ST}+\mathrm{EB}}$ and $Y_{\mathrm{CO}+\mathrm{CO}_{2}}$ which is higher than that over CsX-c. Although parts of the strong base sites provided by the alkali oxide itself might be exposed by the pretreatment at $550{ }^{\circ} \mathrm{C}$ in this work, it should be occupied again by $\mathrm{CO}_{2}$ formed in situ as $\mathrm{CO}_{2}$ can be formed during the reaction process (Table S3†), which should account for the similar reaction results over $8 \mathrm{CsOx} / \mathrm{CsX}-c$ with or without $\mathrm{CO}_{2}$ pretreatment. Thus, it indicated that the efficient base sites for side-chain alkylation of toluene with methanol corresponding to the $\mathrm{CO}_{2}$ desorption below $400{ }^{\circ} \mathrm{C}$ in Fig. 2. And combined with the analysis of base properties of the catalysts above, it suggested that the promotion for side-chain alkylation of toluene with methanol over the cesium oxide modified CsX was attributed to the enhanced base properties of $\mathrm{O}^{\delta-}$ in the zeolite framework.

In our previous work, ${ }^{4}$ we proposed the concept regarding formaldehyde ([HCHO]) that has been generated from methanol during the reaction processes. The [HCHO], virtual yield of $[\mathrm{HCHO}]\left(Y_{[\mathrm{HCHO}]}\right)$ and conversion of $[\mathrm{HCHO}]$ to styrene and ethylbenzene $\left(X_{(\mathrm{HCHO}}\right.$ to $\left.\left.\mathrm{ST}+\mathrm{EB}\right)\right)$ were defined as (quantities are molar flow rates):

$[\mathrm{HCHO}]=$ styrene $_{\text {outlet }}+$ ethylbenzene outlet $+\mathrm{CO}_{\text {outlet }}+\mathrm{CO}_{2 \text { outlet }}$

$$
Y_{[\mathrm{HCHO}]}=\frac{[\mathrm{HCHO}]}{\text { methanol }_{\text {inlet }}} \times 100 \%
$$

$$
X_{(\mathrm{HCHO} \text { to ST+EB })}=\frac{\text { styrene }_{\text {outlet }}+\text { ethylbenzene }_{\text {outlet }}}{[\mathrm{HCHO}]} \times 100 \%
$$

$X_{(\mathrm{HCHO}}$ to $\left.\mathrm{ST}+\mathrm{EB}\right)$ represents the utilization extent of [HCHO] by side-chain alkylation of toluene. When the cesium ion exchange degree of CsX was higher than $32.3 \%$, the $X_{\text {(HCHO to }}$ ST+EB) over CsX remained constant with the exchanged degree further increased. ${ }^{4}$ However, the $X_{(\mathrm{HCHO}}$ to $\left.\mathrm{ST}+\mathrm{EB}\right)$ decreased when CsX- $c$ was modified by alkali oxides, and the decrease trend was in the order of $8 \mathrm{NaOx} / \mathrm{CsX}-c>8 \mathrm{KOx} / \mathrm{CsX}-c>8 \mathrm{CsOx} /$ CsX- $c$, suggesting that different influences have been imparted on the $\mathrm{O}^{\delta-}$ in the zeolite framework by improving cesium ion exchanged degree and modifying with alkali oxides. Reaction results over CsX-6 (cesium exchanged degree is 59.2\%), taken from our preceding paper, ${ }^{4}$ were compared with $8 \mathrm{NaOx} / \mathrm{CsX}-c$ and $4 \mathrm{CsOx} / \mathrm{CsX}-c$ (Fig. 6), as the $S_{\mathrm{int}}$ of the three catalysts is similar to each other. The base strength of CsX-6 and 4CsOx/ CsX- $c$ was similar to each other, but the base sites amount of CsX-6 was larger than that of $4 \mathrm{CsOx} / \mathrm{CsX}-c$ (Fig. S3 $\dagger$ ), however, the $X_{\text {methanol }}$ over $4 \mathrm{CsOx} / \mathrm{CsX}-c$ was higher than that over CsX-6, suggesting that the base strength enhanced $\mathrm{O}^{\delta-}$ in $4 \mathrm{CsOx} / \mathrm{CsX}-c$ were more inclined to adsorb and activate methanol instead of toluene, which might be due to the different location of the introduced base sites in $4 \mathrm{CsOx} / \mathrm{CsX}-c$ with that in CsX-6. Generally, the adsorption of toluene in zeolite $\mathrm{X}$ was at SII sites in the supercage of CsX. ${ }^{42}$ The lower $X_{\text {toluene }}$ and higher

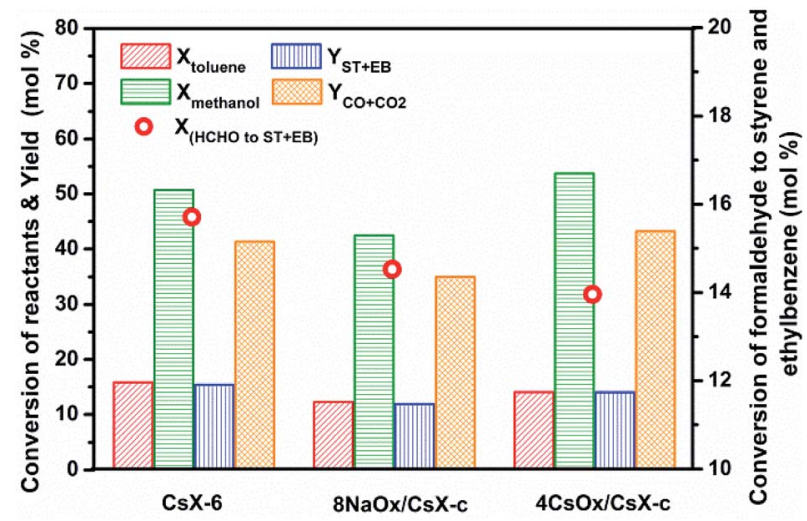

Fig. 6 Reaction behaviors of side-chain alkylation of toluene with methanol over catalysts with similar $S_{\text {int }}$

\begin{tabular}{|c|c|c|c|c|c|}
\hline Catalysts & $\begin{array}{l}\text { Pretreatment } \\
\text { conditions }\end{array}$ & $X_{\text {toluene }}(\%)$ & $X_{\text {methanol }}(\%)$ & $Y_{\mathrm{ST}+\mathrm{EB}}$ & $Y_{\mathrm{CO}+\mathrm{CO}_{2}}$ \\
\hline $\operatorname{CsX}-c$ & Without $\mathrm{CO}_{2}$ & 6.99 & 22.25 & 6.67 & 17.95 \\
\hline $8 \mathrm{CsOx} / \mathrm{CsX}-c$ & With $\mathrm{CO}_{2}{ }^{a}$ & 17.46 & 66.06 & 16.56 & 56.71 \\
\hline
\end{tabular}

Table 1 The influence of pretreating catalyst with $\mathrm{CO}_{2}$ for side-chain alkylation of toluene with methanol

${ }^{a}$ The catalyst was pretreated with $40 \mathrm{~mL} \min ^{-1} \mathrm{CO}_{2}$ at $80{ }^{\circ} \mathrm{C}$ for $30 \mathrm{~min}$, and then swept with helium for 30 min at $400{ }^{\circ} \mathrm{C}$ before introducing the reactants. 
$Y_{\mathrm{CO}+\mathrm{CO}_{2}}$ over $4 \mathrm{CsOx} / \mathrm{CsX}-\mathrm{c}$ indicated that formaldehyde generated over the strength enhanced $\mathrm{O}^{\delta-}$ would preferentially decompose to CO to react with toluene at SII sites, and most of the strength enhanced $\mathrm{O}^{\delta-}$ in alkali oxides modified CsX were far away from the SII sites in the supercage. The more easy decomposition of the generated formaldehyde over the introduced base sites was responsible for the decrease of $X_{(\mathrm{HCHO}}$ to $\mathrm{ST}+\mathrm{EB})$ over the alkali oxides modified CsX.

As shown in Fig. 5(c) and Table $\mathrm{S} 3, \dagger X_{\text {methanol, }} Y_{\mathrm{CO}+\mathrm{CO}_{2}}$ and $Y_{\text {[HсHо }]}$ increased over CsX- $c$ with the increase of cesium oxides amount, which was consistent with the base properties. Nevertheless, $X_{\text {toluene }}$ and $Y_{\mathrm{ST}+\mathrm{EB}}$ increased with increasing cesium oxide amount over CsX-c lower than $8 \mathrm{CsOx}$ per unit cell and then decreased. What is more, the $X_{(\mathrm{HCHO}}$ to $\left.\mathrm{ST+EB}\right)$ decreased sharply as the loaded cesium oxide increased, indicating that the loading of cesium oxide brought down the utilization of [HCHO], and the lower utilization of [HCHO] at higher cesium oxide loading is the reason for the decrease of $X_{\text {toluene }}$ and $Y_{\mathrm{ST}+\mathrm{EB}}$.

The cesium ion exchange degree of CsX- $a$ is only $21.8 \%$ which is too low to provide enough base strength to activate the

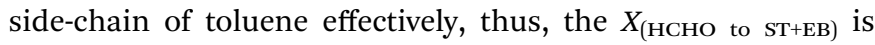
lower than that of CsX- $b$ and CsX-c (Fig. 5(d)). ${ }^{4}$ Meanwhile, there is Brønsted acid sites existed in CsX- $a$ (Fig. S2 $\dagger$ ) which will result in the formation of xylene, ${ }^{4}$ and the dehydrogenation of methanol to formaldehyde will also be restricted as the base strength of CsX- $a$ is very low. Thus, the product from reaction between toluene and methanol over CsX- $a$ is mainly xylene instead of styrene and ethylbenzene (Table S3 $\dagger$ ). When CsX- $a$ is modified with cesium oxide, the base properties of CsX- $a$ is enhanced as well as the Brønsted acid sites was removed (Fig. 2(c) and S2 $\dagger$ ), which lead to the main hydrocarbon products changed from xylene to styrene and ethylbenzene (Table S2†). Finally, the $X_{(\mathrm{HCHO}}$ to $\left.\mathrm{ST}+\mathrm{EB}\right)$ increased due to more effective activation of toluene over the base sites of 8CsOx/CsX- $a$ (Fig. 5(d)).

3.3.2. The conversion of styrene to ethylbenzene over the alkali oxides modified CsX. During the reaction process of side-

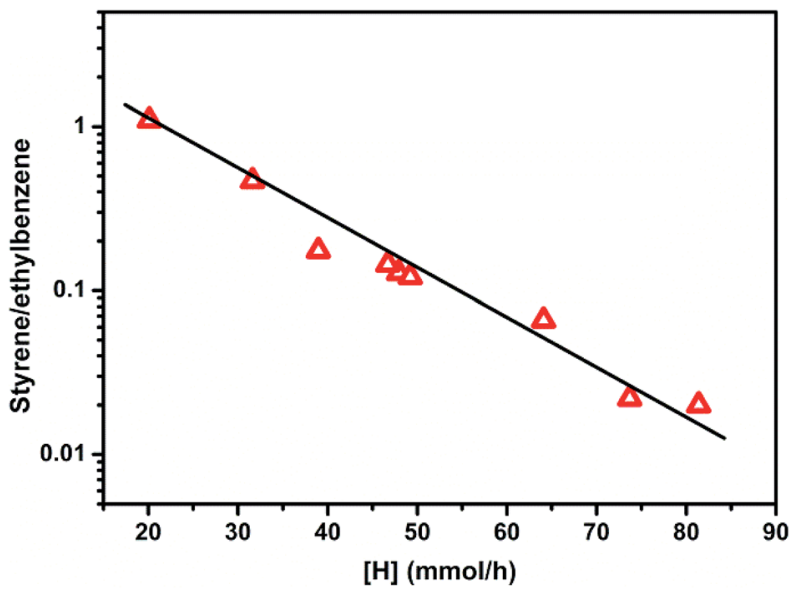

Fig. 7 The styrene/ethylbenzene in the products over the alkali oxides modified $\mathrm{CsX}$ and $\mathrm{CsX}-\mathrm{C}$ as a function of $[\mathrm{H}]$ that has been generated during the side-chain alkylation of toluene with methanol. chain alkylation of toluene with methanol, it is unavoidable that parts of the generated styrene will further be converted to ethylbenzene. And, it can be found from Table S3† that the ST/EB over most of the alkali oxides modified CsX is very low, indicating that most of the produced styrene was further converted into ethylbenzene. Hattori et al. suggested that transfer hydrogenation of styrene with methanol was the main formation path of ethylbenzene. ${ }^{43}$ According to our recent work, ${ }^{4}$ in addition to the transfer hydrogenation of styrene with methanol, the transfer hydrogenation of styrene with the generated formaldehyde was also responsible for the formation of ethylbenzene, and the nature of the transfer hydrogenation of styrene was derived from hydrogenation of styrene with the "active hydrogen atoms ([H])". The hydrogen atom in methanol and formaldehyde could be activated over the base sites during the process of dehydrogenation of methanol and decomposition of formaldehyde, and the $[\mathrm{H}]$ refers to the activated hydrogen atoms during the short time between activation at the base sites and formation of hydrogen molecule. Hence, the amount of the $[\mathrm{H}]$ that has been produced can be calculated as (quantities are molar flow rates):

$$
[\mathrm{H}]=\left([\mathrm{HCHO}]+\mathrm{CO}_{\text {outlet }}+\mathrm{CO}_{2 \text { outlet }}\right) \times 2
$$

The ST/EB over CsX-c and all the alkali oxides modified CsX as a function of $[\mathrm{H}]$ that has been generated during the sidechain alkylation of toluene with methanol is shown in Fig. 7. CsX- $a$ and CsX- $b$ was not included in Fig. 7 as the Brønsted acid sites can be detected on them which would lead to different ethylbenzene formation path. ${ }^{4}$ As shown in Fig. 7, the ST/EB decreased with the increase of the generated $[\mathrm{H}]$, indicating that the lower ST/EB over the alkali oxides modified CsX was attributed to the high generation of $[\mathrm{H}]$. When CsX was modified with alkali oxides, the increase of both base sites amount and base strength will lead to the promotion of methanol dehydrogenation to formaldehyde, which was responsible for the promoted generation of $[\mathrm{H}]$ and reduced ST/EB. On the other hand, compared to CsX, the lower utilization of [HCHO] over the alkali oxide modified CsX which led to more decomposition of [HCHO] was also liable for the low ST/EB over the alkali oxides modified CsX.

\section{Conclusions}

In this study, a series of alkali oxides modified CsX with different base properties gradient were prepared together with cesium oxide modified pure silica zeolite $\beta$ as a comparison sample. Base on the investigation of the base properties of all the samples, it can be concluded that the base properties of $\mathrm{O}^{\delta-}$ in the zeolite framework can be promoted by electron donating function of alkali oxides in the supercage of the CsX. The base properties of the $\mathrm{O}^{\delta-}$ in the framework of CsX, increased with the increase of loading amount of alkali oxides, electron donating capacity of the alkali oxides and the base strength of the parent zeolite. The relation between the base properties and the reaction performance of side-chain alkylation of toluene 
with methanol of the indicated catalysts was also analyzed. It is found that the enhanced base strength of $\mathrm{O}^{\delta-}$ in the CsX framework could promote dehydrogenation of methanol to formaldehyde which account for the promotion effect on sidechain alkylation of toluene with methanol over the alkali oxides modified CsX. At the same time, the increased base properties of the modified CsX promote the decomposition of the formaldehyde, which results in a decrease in utilization of the generated formaldehyde in side-chain alkylation of toluene. With a loading amount increase of cesium oxide on CsX, the yield of styrene and ethylbenzene rises at first and then goes down. The yield reaches the highest when CsX is loaded with 8CsOx per unit cell. Additionally, the strong base properties of the alkali oxides modified CsX stimulates the formation of active hydrogen atoms, giving rise to a lower ST/EB in the products.

\section{Conflicts of interest}

There are no conflicts to declare.

\section{Acknowledgements}

This work is supported by National Natural Science Foundation of China (No. 21576252).

\section{References}

1 Y. N. Sidorenko, P. N. Galich, V. S. Gutyrya, V. G. Ilin and I. E. Neimark, Dokl. Akad. Nauk SSSR, 1967, 173, 132-134.

2 A. J. Martín, S. Mitchell, O. Scholder, R. Verel, R. Hauert, L. Bernard, C. Jensen, M. Schwefer and J. Pérez-Ramírez, ChemPhysChem, 2018, 19, 437-445.

3 H. Chen, X. Li, G. Zhao, H. Gu and Z. Zhu, Chin. J. Catal., 2015, 36, 1726-1732.

4 P. Li, Q. Han, X. Zhang, Y. Yuan, Y. Zhang, H. Guo, L. Xu and L. Xu, Catal. Sci. Technol., 2018, 8, 3346-3356.

5 W. O. Alabi, B. B. Tope, R. B. Jermy, A. M. Aitani, H. Hattori and S. S. Al-Khattaf, Catal. Today, 2014, 226, 117-123.

6 A. E. Palomares, G. Eder-Mirth, M. Rep and J. A. Lercher, J. Catal., 1998, 180, 56-65.

7 D. Barthomeuf, Microporous Mesoporous Mater., 2003, 66, 114.

8 H. Han, M. Liu, X. Nie, F. Ding, Y. Wang, J. Li, X. Guo and C. Song, Microporous Mesoporous Mater., 2016, 234, 61-72.

9 X. Li, J. Lu, Y. Li and J. Yu, Chin. J. Chem., 2017, 35, 716-722. 10 R. J. Davis, J. Catal., 2003, 216, 396-405.

11 E. J. Doskocil and R. J. Davis, J. Catal., 1999, 188, 353-364.

12 J. Engelhardt, J. Szanyi and J. Valyon, J. Catal., 1987, 107, 296-306.

13 H. Hattori, A. A. Amusa, R. B. Jermy, A. M. Aitani and S. S. AlKhattaf, J. Mol. Catal. A: Chem., 2016, 424, 98-105.
14 P. E. Hathaway and M. E. Davis, J. Catal., 1989, 119, 497-507. 15 D. Archier, G. Coudurier and C. Naccache, in Proceedings of the 9th International Zeolite Conference, ed. R. Van Ballucos, et al., Butterworth-Heinemann, 1993, vol. 2, pp. 525-534.

16 M. D. Romero, G. Ovejero, A. Rodríguez and J. M. Gómez, Microporous Mesoporous Mater., 2005, 81, 313-320.

17 D. Barthomeuf, Catal. Rev., 1996, 38, 521-612.

18 Y. Ono and H. Hattori, Solid Base Catalysis, Tokyo Institute of Technology Press, Tokyo, 2011, pp. 178-184.

19 S. V. Bordawekar and R. J. Davis, J. Catal., 2000, 189, 79-90.

20 J. Li and R. J. Davis, Appl. Catal., A, 2003, 239, 59-70.

21 H. Tsuji, F. Yagi and H. Hattori, Chem. Lett., 1991, 18811884.

22 F. Yagi and H. Hattori, Microporous Mater., 1997, 9, 247-251.

23 U. Schenk, M. Hunger and J. Weitkamp, Magn. Reson. Chem., 1999, 37, S75-S78.

24 M. Hunger, U. Schenk, B. Burger and J. Weitkamp, Angew. Chem., Int. Ed. Engl., 1997, 36, 2504-2506.

25 M. A. Camblor, A. Corma and S. Valencia, J. Mater. Chem., 1998, 8, 2137-2145.

26 J. Li and R. J. Davis, J. Phys. Chem. B, 2005, 109, 7141-7148.

27 J. Weitkamp, S. Ernst, M. Hunger, T. Röser, S. Huber, U. A. Schubert, P. Thomasson and H. Knözinger, Stud. Surf. Sci. Catal., 1996, 101, 731-740.

28 F. Yagi, N. Kanuka, H. Tsuji, S. Nakata, H. Kita and H. Hattori, Microporous Mater., 1997, 9, 229-235.

29 M. Laspéras, H. Cambon, D. Brunel, I. Rodriguez and P. Geneste, Microporous Mater., 1996, 7, 61-72.

30 M. Sánchez-Sánchez and T. Blasco, J. Am. Chem. Soc., 2002, 124, 3443-3456.

31 W. J. Mortier, J. Catal., 1978, 55, 138-145.

32 N. Giordano, L. Pino, S. Cavallaro, P. Vitarelli and B. S. Rao, Zeolites, 1987, 7, 131-134.

33 D. Barthomeuf, Stud. Surf. Sci. Catal., 1991, 65, 157-169.

34 V. Bosacek, Z. Phys. Chem., 1995, 189, 241-250.

35 M. Huang, A. Adnot and S. Kaliaguine, J. Catal., 1992, 137, 322-332.

36 M. Huang, A. Adnot and S. Kaliaguine, J. Am. Chem. Soc., 1992, 114, 10005-10010.

37 Y. Okamoto, M. Ogawa, A. Maezawa and T. Imanaka, J. Catal., 1988, 112, 427-436.

38 T. L. Barr, Zeolites, 1990, 10, 760-765.

39 W. J. Mortier, Struct. Bonding, 1987, 66, 125-143.

40 S. T. King and J. M. Garces, J. Catal., 1987, 104, 59-70.

41 H. Itoh, T. Hattori, K. Suzuki and Y. Murakami, J. Catal., 1983, 79, 21-33.

42 J. Zhu, N. Mosey, T. Woo and Y. Huang, J. Phys. Chem. C, 2007, 111, 13427-13436.

43 H. Hattori, W. O. Alabi, B. R. Jermy, A. M. Aitani and S. S. AlKhattaf, Catal. Lett., 2013, 143, 1025-1029. 